\title{
TOOMPEA HILL STABILITY ANALYSIS
}

\author{
Jüri-Rivaldo Pastarus \\ Tallinn Technical University, \\ Ehitajate tee, 5, Tallinn, EE 0026, Estonia
}

\section{INTRODUCTION}

On Toompea Hill situated in the center of Tallinn there are several natural, ancient architectural and historical monuments. It has become apparent that the processes in the rock mass caused an unfavorable environmental side effect accompanied by significant subsidence of the Toompea Hill.

Identification of the reasons of the Toompea Hill's subsidence and opening the physical substance of these processes is the main aim of the present work. For the feasibility study stability problems were investigated. Accordingly, it was decided to perform numerical modeling analysis using two-dimensional Fast Lagrangian Analysis of Continua (FLAC - program) (1). It is suitable for stability analysis, for parametric and sensitivity studies.

For the first time, preliminary calculations before the modeling have been proposed. This method enabled to simplify and quicken the further modeling. It was made by means of conventional calculation methods, using theoretical formulas. The utility of preliminary calculations was clearlyproved.

At first, little field information was available to estimate the rock mass properties. For this estimation, geological data were used. The rock mass properties were selected, based on Bieniawski's rock mass rating (RMR) (2).

\section{GEOLOGY}

Precambrian crystalline igneous and metamorphic rocks form the base of the area of Tallinn. Lower Paleozoic sedimentary rocks lie on the crystalline base rock, which is covered with Quaternary clastic 
rocks (Fig.1). During the Pre-Quatemary period, ancient valleys were incised through Cambrian clays and the underlying sandstones. Later the ancient valleys was filled by fluvio-glacial sand - and - gravel deposits, Quaternary lacustrine-glacial flowing and plastic clays, loams.

Consolidated Cambrian clays form a waterproof roof for the confined Cambrian-Vendian aquifer of the thickness about $50 \mathrm{~m}$. It is one of water sources for Tallinn. Owing to strong underground pumping in the center of cone of depression the lowering of the potentiometric surface (about $30 \mathrm{~m}$ ) attains.

Unconfined Ordovician-Cambrian aquiter-aquitard system is separated from Cambrian-Vendian system by $85-90 \mathrm{~m}$ thick Cambrian clays. $18-22 \mathrm{~m}$ thick sandstone layer represents the aquifer. The water table of this layer fluctuates from 0,4 to $1,0 \mathrm{~m}$.

The waters in the ancient buried valleys are hydraulically connected with the aquifereous strata.

Toompea Hill is situated between two ancient buried valleys (see Fig. 1.A). The height of Toompea Hill is $24 \mathrm{~m}$ ( $47 \mathrm{~m}$ above sea level) and the dimensions in different directions are: $\mathrm{NE}-\mathrm{SW}-300 \mathrm{~m}, \mathrm{NW}-\mathrm{SE}$ $200 \mathrm{~m}$. It is represented by Quaternary, Ordovician and Cambrian sediments (Fig.2). Field investigations of Toompea Hill were carried out by means of a boring program. The number of boring holes. was 6 bored at different depth from 26 to $68 \mathrm{~m}$. Several laboratory tests of the rock samples have been carried out.

Surface water is situated in the cracked Ordovician limestones and dolomites. The argellite clay layer form a waterproof bottom. It is feed on the water from rain and snow, which infiltrates into terrain and dissolves carbonate rocks to saturation level. Abovementioned process may influence on the stability of the Toompea Hill and consequently, demands the supplementary investigations.

\section{THEORETICAL MODEL}

On the bases of the investigations by $\mathrm{L}_{\text {. }}$ Vallner and $\mathrm{R}$. Lutsar, the total subsidence of the territory of Tallinn can be calculated by following formula $(3,4)$ :

$N(t)=-A(t)+B(p)+C(p)+D(t)+E(t)+F(t)+G(p)+K(t)+S(t)$ 
where $N(t)$, total subsidence of the territory of Tallinn; $A(t)$, surface displacement, caused by the tectonic processes; $B(p)$, surface displacement caused by the atmospheric pressure; $C(p)$, unconfined aquifer elastic deformation, caused by the decrease of the water table; $D(t)$, unconfined aquitard plastic deformation, caused by the decrease of the water table; $E(t)$, soil compaction, caused by the buildings; $F(t)$, soil compaction, caused by the vibrations; $G(p)$, confined aquifer plastic deformation, caused by the decrease of the potentiometric surface; $K(t)$, confined aquitard plastic deformation, caused by the decrease of the potentiometric surface; $\mathrm{S}(\mathrm{t})$, clays compaction in ancient buried valleys.

The influence of the different factors on the surface subsidence in the territory of Tallinn is represented in Table 1. (3). Analysis showed that the subsidence mainly depends on the behavior of OrdovicianCambrian and Cambrian-Vendian aquifer-aquitard systems. As is known, the process of aquitard drainage leads to compaction of the aquitards just the process of aquifer drainage leads to compaction of the aquifer. The deformations of the aquitard are seemly inconsiderable, owing to the rather great density of the Cambrian clays (4). Accordingly, for the first stage of the project, only the Ordovician-Cambrian and CambrianVendian aquifer compaction was investigated.

If the weight of overlying material remains constant and the potentiometric surface in the confined aquifer or the water table in the unconfined aquifer is decreased, the stratum compaction is $(4,5)$ :

$$
\mathrm{db}=\alpha \mathrm{b} \Delta \mathrm{p}
$$

where $d b$, the change in the thickness of the stratum; $\alpha$, compressibility; $b$, thickness of the saturated zone; $\Delta p$, the increase of the effective pressure.

The increase of the effective pressure is calculated by following formulas (5):

$$
\Delta \mathrm{p}=\gamma \Delta \mathrm{h} \quad \text { or } \quad \Delta \mathrm{p}=\left(\gamma_{2}-\gamma_{1}\right) \Delta \mathrm{H}
$$

where $\gamma$, the weight density of water; $\Delta h$, the decrease of the hydraulic head in the aquifer; $\gamma_{2}$, the weight density of rocks in the unsaturated zone; $\gamma_{1}$, the weight density of rocks in the saturated zone; $\Delta H$, the decrease of the water table. 


\section{NUMERICAL MODELING}

For the evaluation, the two-dimensional Fast Lagrangian Analysis of Continua (FLAC) was used (1). FLAC is an explicit tinite difference code which utilizes the "Lagrangian" calculation scheme and explicit time stepping algorithm. It has several built in material behavior models. In addition it contains groundwater and consolidation (fully coupled) models.

The problems assumes isotropic Darcy flow for fluid transport. The soil grain skeleton is assumed to behave elastically. The water is assumed to flow in the vertical direction only, and there is no horizontal strain (one-dimensional problem) (see Fig.3). The applicability of the one-dimensional models depends on the physical substance of the modeled processes and was demonstrated by spetial investigations (4). Here, the methodology for rock mechanics modeling in data limited conditions was used (6). Two different models regarding the behavior of the aquifer-aquitard system have been presented here: a) for the confined Cambrian-Vendian aquifer; b) for the unconfined Ordovician-Cambrian aquifer.

The resulting rock mass responses are presented in terms of induced principal stress and displacement contours.

\section{MODEL PROPERTIES}

During the first stage of the project, when relatively little field information is available, it is reasonable to estimate the rock mass properties from geological data. The selection of all rock properties was based on Bieniawski's rock mass rating (RMR) (2). The elasticity and compressibility parameters for the aquifer was precised by using the special investigations $(3,4)$. By combining the field observations, laboratory tests and the RMR - system, a good approximation for rock mass properties was constructed (Table 2).

\section{RESULTS}

Analysis showed that the Toompea Hill stability is connected with the subsidence of the territory of Tallinn and Ordovician aquifer-aquitard 
system. Surface subsidence is caused by Cambrian-Vendian and Ordovician-Cambrian aquifer. Owing to the rather great density of the aquitard, the deformation one are seemly inconsiderable.

The decrease of the water table in the unconfined Ordovician-Cambrian aquifer by $1 \mathrm{~m}$ gives the deformation of this layer from 1,0 to $2,5 \mathrm{~mm}$ and respectively for confined Cambrian-Vendian aquifer from 0,05 to $0,1 \mathrm{~mm}$.

The results of the modeling and measuring of the deep-seated ground bench-mark are in the same magnitude.

\section{CONCLUSIONS}

As a result of the study, the following conclusions and recommendations can be made.

1. The Toompea Hill stability is connected with the subsidence of the territory of Tallinn. For the most part, the surface subsidence is caused by Ordovician-Cambrian and Cambrian-Vendian aquifers-aquitard systems.

2. The preliminary calculations enabled to simplify and quicken the further modeling. The method for rock mechanics modeling in data limited conditions improves the quality of the investigations.

3. Investigations show that the deformation of the aquifer-aquitard systems by the results of the modeling and deep-seated ground bench-mark are in the same magnitude.

4. This study was based on assumed properties of the rock mass and aquifer-aquitard systems. Other combinations of these parameters may give different results. Therefore, a sensitivity study is recommended to be performed.

\section{ACKNOWLEDGMENTS}

I am very grateful to $\mathrm{Ph}$. D. Leo Vallner of Geological Survey of Estonia for his great help and valuable comments.

The research was financially supported by Estonian Science Foundation, Grant No. 2108, 1996 - 1998. 


\title{
REFERENCES
}

1. FLAC, Fast Lagrangian Analysis of Continua, version 3.3, Vol.1;2. User Manual. Itasca Consulting Group, Inc., Minneapolis, 1995.

2. Hoek E. and Brown E. T. Underground Excavations in Rock. Inc. of Mining and Metallurgy, London, 1980.

3. Arbeiter R., Vallner L., Saapar L. and Savitsky L. Surface subsidence in Estonia. Water resources. - No.2. - Moscow, 1982, 64,- 78. P. (in Russian).

4. Vallner L. and Lutsar R. On the deformations of the Earth's surface on the territory of Tallinn. Proc. of the second International Symposium on Recent Crystal Movements. - Helsinki, 1966. - 387. 394. P.

5. Freeze R. A., Cherry J. A. Groundwater. Prentice Hall, Englewood Cliffs. - New Jersy, 1979.

6. Starfield A. M., Cundall P. A. Towards a methodology for rock mechanics modeling. Int. J. Rock Mech. Min. Sci. \& Geomech. Abstr., Vol.25. - No.3. - 1988. - 99. - 106. P.

\begin{abstract}
This paper analyses the stability of the Toompea Hill, using the theoretical and numerical modeling. Calculation were performed by the FLAC-program. Rock properties were estimated from geological data by Bieniawski's rock mass rating. The results demonstrate that Toompea Hill stability is connected with the subsidence of the territory of Tallinn, where the compaction of Ordovician-Cambrian and Cambrian-Vendian aquifer-aquitard systems cause the surface subsidence.
\end{abstract}

KEY WORDS: stability, rock mass, model, weight density, aquiferaquitard system, hydraulic head, water table, surface subsidence. 


\section{FIGURES}

A

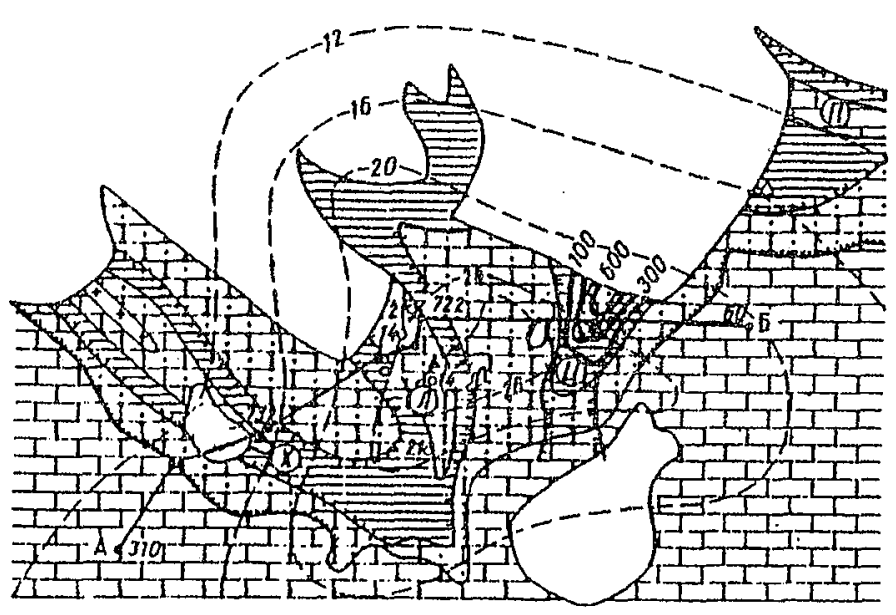

B

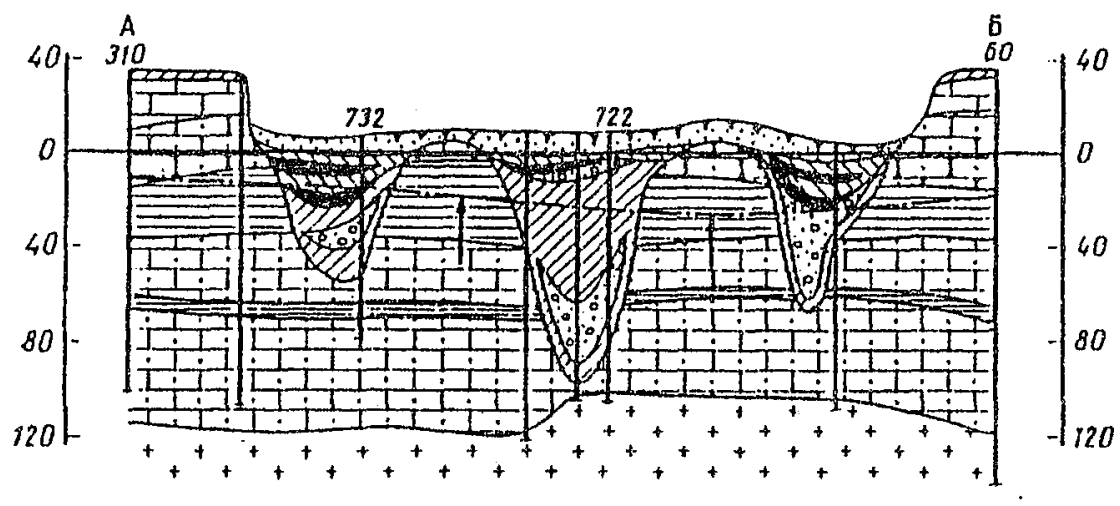



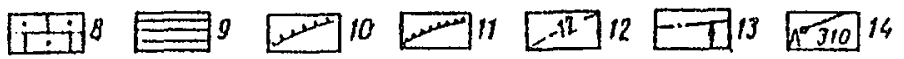

1 - soil; 2 - sand; 3 - crystalline rocks; 4 - flowing-plastic clay; 5 - sand and gravel; 6 - morainic loam; 7 - hard limestone; 8 - solid sandstone; 9 - solid clay; 10 - contours of ancient buried valleys; 11 - Baltic Klint; 12 - isopiezes of Cambrian-Vendian aquifer stratum; 13 - piezometrical surface of CambrianVendian aquifer stratum; 14 - profile.

Fig. 1. Schematic geological map (A) and section (B) of the Tallinn area $(3,4)$. 


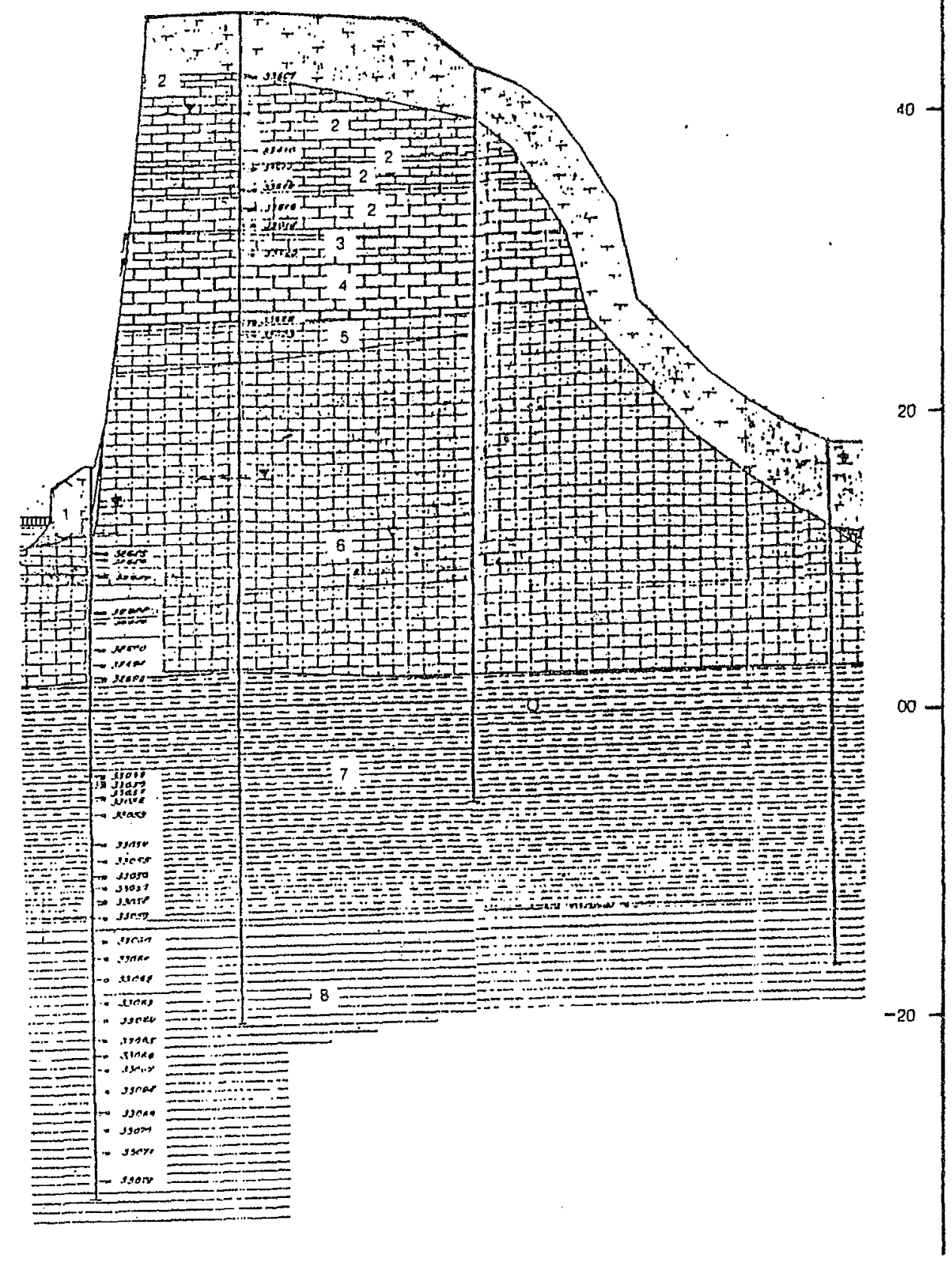

1 - Quatemary sediments; 2 - limestone; 3 - soft sandstone; 4 - argillite; 5 and 6 - sandstone; 7 - clay and siltstone; 8 - clay.

Fig. 2. Geological section of the Toompea Hill 


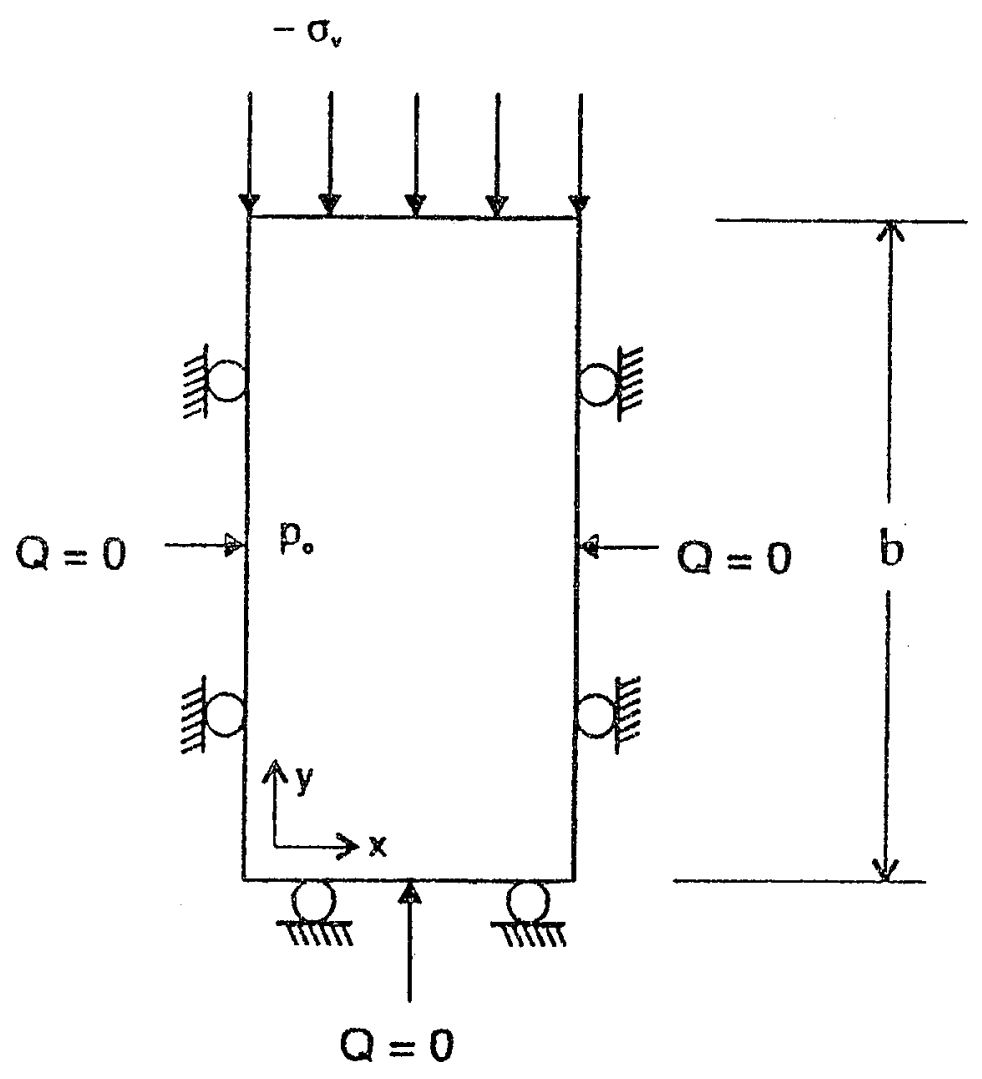

ov - applied vertical pressure; $p_{0}$ - initial excess pore pressure; $Q$ - outflow (inflow) rate of water; $b$ - thickness of the stratum.

Fig. 3. Conceptual model 


\section{TABLES}

Table 1

\section{Influence of the different factors on the total subsidence of the territory of Tallinn between the buried valleys (by Vallner, $L$ et al.)}

\begin{tabular}{|c|c|c|}
\hline Parameter & Value & Observation \\
\hline $\begin{array}{l}A(t) \text { - surface displacement, } \\
\text { caused by the tectonic pro- } \\
\text { cesses, mm/year }\end{array}$ & -1.7 & $\begin{array}{r}\text { Erom } 1911 \\
\text { to } 1980 \\
<0.1 \mathrm{~m}\end{array}$ \\
\hline $\begin{array}{l}B(p) \text { - surface displacement, } \\
\text { caused by the atmospheric } \\
\text { pressure, mm }\end{array}$ & $0.1-0.2$ & $\max <0.5 \mathrm{~mm}$ \\
\hline $\begin{array}{l}C(p) \text { - Ordovician-Cambrian } \\
\text { aquifer elastic deformation, } \mathrm{mm}\end{array}$ & $0.5-1.0$ & $\begin{array}{l}\text { by } \Delta \mathrm{h}= \\
0.4-1.0 \mathrm{~m}\end{array}$ \\
\hline $\begin{array}{l}D(t) \text { - Ordovecian-Cambrian aqui- } \\
\text { tard plastic deformation, } \mathrm{mm} / \mathrm{yar}\end{array}$ & $<0.1$ & $\begin{array}{l}\text { by } \Delta h= \\
0.4-1.0 \mathrm{~m}\end{array}$ \\
\hline $\begin{array}{l}E(t) \text { - soil compaction, caused } \\
\text { by buildings, } \mathrm{mm}\end{array}$ & 100 & $\begin{array}{l}P=0.1- \\
-0.15 \mathrm{MN} / \mathrm{m}^{2}\end{array}$ \\
\hline $\begin{array}{l}\text { F(t) - soil compaction, caused } \\
\text { by vibrations, } \mathrm{mm}\end{array}$ & - & unknown \\
\hline $\begin{array}{l}G(p) \text { - Cambrian-Vendian aqufer } \\
\text { elastic deformation, } \mathrm{mm}\end{array}$ & $1-2$ & $\begin{array}{l}\text { from } 1900 \\
\Delta \mathrm{h}=30 \mathrm{~m}\end{array}$ \\
\hline $\begin{array}{l}K(t) \text { - Cambrian-Vendian aquitard } \\
\text { plastic deformation, } \mathrm{mm}\end{array}$ & $30-50$ & $\begin{array}{l}\text { from } 1900 \\
\Delta \mathrm{h}=30 \mathrm{~m}\end{array}$ \\
\hline
\end{tabular}

Note: $\Delta \mathrm{h}$ - decrease of the water table or hydraulic head in the aquiter; $\mathrm{p}$ - pressure, caused by the foundation. 
Table 2

Rock mass and hydroulic properties used for modeling

\begin{tabular}{|l|c|c|}
\hline Parameter & $\begin{array}{r}\text { Ordovician- } \\
\text {-Cambrian }\end{array}$ & $\begin{array}{r}\text { Cambrian- } \\
\text {-Vendian }\end{array}$ \\
\hline Density (saturated), $\mathrm{kg} / \mathrm{m}^{3}$ & 2020 & 2200 \\
Bulk modulus (dry), $\mathrm{Pa}$ & $1.310^{8}$ & $1.110^{10}$ \\
Shear modulus (dry), $\mathrm{Pa}$ & $810^{7}$ & $6.810^{9}$ \\
Bulk modulus, fluid, $\mathrm{Pa}$ & $210^{9}$ & $210^{9}$ \\
Permeability, (m/sec)/(Pa/m) & $510^{-7}$ & $110^{-9}$ \\
Porosity & 0.33 & 0.29 \\
\hline
\end{tabular}

